\title{
Optimization of Irrigation Water Allocation Framework Based on Genetic Algorithm Approach
}

\author{
Godwin Jiya Adama1, David Onemayin Jimoh ${ }^{1}$, Martins Yusuf Otache ${ }^{2}$ \\ ${ }^{1}$ Department of Civil Engineering, Federal University of Technology, Minna, Nigeria \\ ${ }^{2}$ Department of Agricultural and Bio-Resources Engineering, Federal University of Technology, Minna, Nigeria \\ Email: godwinadama@yahoo.co.uk
}

How to cite this paper: Adama, G.J., Jimoh, D.O. and Otache, M.Y. (2020) Optimization of Irrigation Water Allocation Framework Based on Genetic Algorithm Approach. Journal of Water Resource and Protection, 12, 316-329.

https://doi.org/10.4236/jwarp.2020.124019

Received: March 14, 2020

Accepted: April 18, 2020

Published: April 21, 2020

Copyright $\odot 2020$ by author(s) and Scientific Research Publishing Inc. This work is licensed under the Creative Commons Attribution International License (CC BY 4.0).

http://creativecommons.org/licenses/by/4.0/

\begin{abstract}
In a world where excessive use and degradation of water resources are threatening the sustainability of livelihoods dependent on water and agriculture, increased food production will have to be done in the face of a changing climate and climate variability. There is a need to make optimal use of the available water resource to maximize productivity. Climate-smart irrigation is aimed at increasing per unit production and income from irrigated cropping systems without having negative impacts on the environment or other water users and uses. This paper developed a water allocation model using Genetic Algorithm to equitably allocation available water to the various sectors in Kano River Irrigation Scheme yielding an optimal as well as equitable water release with a $96.44 \%$ demand met. An average relative supply of 0.94 was obtained indicating the there was even supply of water to all the sectors. The model is robust and relatively easy to apply and can be employed by farm managers to achieve equity and optimal use of the available water resource.
\end{abstract}

\section{Keywords}

Climate-Smart Agriculture, Irrigation, Water Allocation, Sectors, Relative Water Supply

\section{Introduction}

Global water resources are under increasing pressure due to large-scale water abstraction for human needs [1] [2]. Agriculture is both a cause and victim of water scarcity, as the excessive use and degradation of water resources are threatening the sustainability of livelihoods dependent on water and agriculture [3]. Water scarcity is said to occur when demand for freshwater exceeds supply 
in a specified domain and of all sectors of the economy; agriculture is the most sensitive to water scarcity. Although the agricultural sector is sometimes viewed as a "residual" user of water, after domestic and industrial sectors, it accounts for 70 percent of global freshwater withdrawals, more than 90 percent of consumptive use [4]. About 70\% of this water abstracted from freshwater systems is used for irrigation [5], yet, irrigation systems are under pressure to produce more food with lower supplies of water [6]. Although farmers have long adapted to environmental conditions, the severity of the predicted climate changes may be beyond many farmers' current ability to adapt and improve their agricultural production systems and livelihoods [7]; increased food production will have to be done in the face of a changing climate and climate variability [8]. The vulnerability of agriculture is increasing with the passage of time as climate change is badly affecting agriculture due to uncertainty in the availability and quality of natural resources [9]. However, there is an increasing interest focused on ensuring that both agriculture and irrigation become climate smart as a driven factor to ensure food security, improve rural livelihoods, and alleviate environmental risks for small-scale farmers [10].

Climate-smart agriculture (CSA) is the agriculture that sustainably increases productivity, enhances resilience, reduces or removes greenhouse gases where possible and enhances achievement of national food security [11]. The CSA has three concurrent objectives: 1) sustainably increasing farm productivity and income, 2) increasing adaptive capacity to climate change, and 3) reducing greenhouse gas emissions [12]. Climate-smart irrigation (CSI) is an important integral component of climate-smart agriculture. It is an irrigation approach for a given agro-climatic and societal context that may result directly or indirectly from the different aspects of climate change; it aims to increase per unit production and income from irrigated cropping systems without having negative impacts on the environment or other water users and uses (in space and time).

The performance of agricultural use of irrigation water in sub-Sahara Africa, as compared to Asia, has been characterized by inefficiency and poor management [13]. According FAO (2018) Sub-Saharan Africa (SSA) has the most significant potential for expanding irrigated agriculture in the world. But only one-fifth of the potential irrigable area has been developed despite its enormous land and water resources [14], of which the vast majority of this irrigated land is concentrated in just four countries: Madagascar, Nigeria, South Africa, and Sudan [15].

Irrigation practice in Nigeria has not achieved the set goals despite the huge investment involved. The available resources for agricultural and irrigation development are still underutilized including land, water resources, and other agricultural inputs [16]. Currently, the total arable land in the country is estimated at about 34.6 million ha; however, only $40 \%$ is under cultivation out of which less than 5\% is irrigated [17] [18]. Notwithstanding the abundant land and water resources, the availability of land for crop production is under threat due to recently increased conflict of the resource among the farmers and the herders in 
some selected agro ecological zones of the country [19]. Although Nigeria irrigation system has recently started receiving due attention and there is an observed facelift in its development, there are still underline challenges that need to be adequately addressed such as inconsistent and unstable policies and inappropriate legal framework, funding constraint and farmers attitudes and awareness towards irrigation systems of crop production and lack of the farmers interested in the operation and maintenance of the large-scale irrigation facilities. [20] reported that poor knowledge of irrigation techniques among the farmers is one of the factors affecting their participation in large-scale irrigation scheme. Those that manage to participate are not equipped with the requisite knowledge for the operations and maintenance of the facilities. This problem is one of the current challenges being faced by the large-scale irrigation scheme in Nigeria. The participating farmers see the facilities as government properties which should be maintained by the government. These do not only make the equipment short-lived but has also resulted in the abandonment of irrigation scheme due to lack of irrigation equipment and infrastructure to make use of. Furthermore, in irrigation scheme like the Hadeja-Jama' are river project, the utilization of the project is just about 50\% while the Zobe dam in Dutsin-Main Katsina, which was constructed 40 years ago, currently has very little irrigation activities. Also, at the Bakolori irrigation dam in Zamfara State, under the Sokoto Rima Water Project, the area cultivated is not commensurate with the amount of water in the dam [21].

Kano River Irrigation Project (KRIP) being one of the first, largest and said to be the best performing irrigation project in Nigeria, has been in existence for over four decades and has not met up to ten percent of the design capacity. The dominant problems as identified by [14] range from water distribution, water management, waterlogging, salinity, sodicity, reduced fertility, obliteration of the irrigation and drainage infrastructure. This paper is focused on addressing water management issues by developing an irrigation water allocation model that will ensure equity in water, ensure the proper management and distribution of water to the users.

\section{Materials and Method}

\subsection{The Study Area}

The study area is located in the Kano State of Nigeria in Kano State between latitudes $11^{\circ} 30^{\prime} \mathrm{N}$ and $12^{\circ} 03^{\prime} \mathrm{N}$ and longitudes $8^{\circ} 30^{\prime} \mathrm{N}$ and $9^{\circ} 40^{\prime} \mathrm{E}$. Kano River Irrigation Project, Phase I (KRIP I) is part of the Kano River Project which began in 1965 as a pilot project. It covers potentially irrigable land of 22,000 ha, which forms the study area. To this end, the area developed for irrigation is 16,500 ha while the area cropped ranges between 13,900 ha for dry season and 16,450 ha in wet seasons. KRIP I is a unique design, in that, the entire water distribution network operates on gravity owing to the elevation of 440 meters above sea level, with a minimum of the supply dam at 506.50 meters [14].

Tiga Dam is the source of irrigation water to the project site through the Ru- 
wan Kanya Reservoir and the $18 \mathrm{~km}$ long main canal II, which splits into West and East branch canals. These are then distributed to all sectors, to sector turnouts, to distributor canals, to field canals and siphoned to blocks or farmlands. The excess is designed to be collected from the end of the field through field drains to collector drains and to main drains and back to the Kano River. The land is cultivated throughout the year (dry and wet season). Rainfall annual mean varies from about $884 \mathrm{~mm}$ to $600 \mathrm{~mm}$ in the north to $1200 \mathrm{~mm}$ in the south. Rain is more in five months (May-September) with August, recording the highest amount and mean annual temperature ranges from $26^{\circ} \mathrm{C}-33^{\circ} \mathrm{C}$. The yearly rainfall amount in Kano is increasing, especially in July and August [22]. Rice, Maize, Wheat, Onions and, Tomato are the main crops along with Sorghum, Vegetables, Cowpea, and Millet [14].

\subsection{Data Collection}

1) Primary Data for KRIP include: Number of sectors, irrigation network, irrigable land, Antecedent cropping pattern.

2) Secondary Data (NIMET and HJRBRDA): Monthly rainfall, temperature (maximum and minimum), relative humidity, sunshine hours, wind speed from (1980-2010) a period of 30 years [23].

\subsection{Methodology}

\subsubsection{Determination of Monthly Evapotranspiration Using the Penman Monteith Evapotranspiration Model}

Evapotranspiration $\left(E T_{o}\right)$ is the combination of evaporation and transpiration of hydrological cycle. Both evaporation and transpiration shows the effect on hydrological cycle. Therefore, it plays a major role in the planning and management of water resources system, irrigation system design and hydrologic and drainage studies [24].

The monthly evapotranspiration of Kano River irrigation project was determined by employing FAO Penman-Monteith equation as shown in Equation (1):

$$
E T_{o}=\frac{0.408 \Delta\left(R_{n}-G\right)+\gamma\left(\frac{900}{T_{\text {mean }}+273}\right) U_{2}\left(e_{s}-e_{a}\right)}{\Delta+\gamma\left(1+0.34 U_{2}\right)}
$$

where $E T_{o}$ is reference evapotranspiration $\left(\mathrm{mm} \cdot \mathrm{day}^{-1}\right), R_{n}$ net radiation at the crop surface $\left(\mathrm{MJ} \cdot \mathrm{m}^{-2} \cdot\right.$ day $\left.^{-1}\right), G$ soil heat flux density $\left(\mathrm{MJ} \cdot \mathrm{m}^{-2} \cdot\right.$ day $\left.^{-1}\right), T$ mean daily air temperature at $2 \mathrm{~m}$ height $\left({ }^{\circ} \mathrm{C}\right), U_{2}$ wind speed at $2 \mathrm{~m}$ height $\left(\mathrm{m} \cdot \mathrm{s}^{-1}\right), e_{s}$ saturation vapour pressure $(\mathrm{kPa}), e_{\mathrm{a}}$ : actual vapour pressure $(\mathrm{kPa}), e_{s}-e_{a}:$ saturation vapour pressure deficit $(\mathrm{kPa}), \Delta$ slope vapour pressure curve $\left(\mathrm{kPa} \cdot{ }^{\circ} \mathrm{C}^{-1}\right)$, while $\gamma$ psychrometric constant $\left(\left(\mathrm{kPa} \cdot{ }^{\circ} \mathrm{C}^{-1}\right)\right.$. Penman-Monteith method has been recommended by the United Nations Food and Agriculture Organization (FAO) as the single method for estimating reference evapotranspiration throughout the world. The FAO-56 based on the Penman-Monteith (Allen et al. 1998) method is considered to be a standard method [25]. 


\subsubsection{Determination of Crop Water Need ( $\left.E T_{\text {crop }}\right)$}

Steps for determining crop evapotranspiration, $E T_{\text {crop: }}$ :

1) Identifying the crop growth stages, determining their lengths, and selecting the corresponding $K_{c}$ coefficients;

2) Adjusting the selected $K_{c}$ coefficients for frequency of wetting or climatic conditions during the stage;

3) Constructing the crop coefficient curve (allowing one to determine $K_{c}$ values for any period during the growing period); and

4) Calculating $E T_{\text {crop }}$ as the product of $E T_{o}$ and $K_{c}$.

The general lengths for the four distinct growth stages and the total growing period for various types of climates and locations were employed as provided by FAO Irrigation and Drainage Paper No. 24 [26]. Crop water need was calculated based on the monthly reference crop evapotranspiration and the crop factor for each crop as shown in Equation (2) below based on FAO 56 standard.

$$
E T_{\text {crop }}=E T_{o} \times K_{c}
$$

where $E T_{\text {crop }}$ is crop water need and $K_{c}$ the crop factor. Crop factor varies for crops at various growth stages which include; initial, crop development, mid and late stages of growth.

\subsubsection{Determination of Crop Water Requirement (CWR)}

Crop water requirement is the amount of water required to compensate the evapotranspiration loss from the cropped field. Crop water requirement for the various sectors on weekly bases were computed for the crop water needs and the area of each sector as shown in Equation (3)

$$
\mathrm{CWR}=E T_{\text {crop }} \times A
$$

where CWR is the crop water requirement, $E T_{\text {crop }}$ is crop water need and $A$ is the area of each sector.

\subsubsection{Determination of Relative Water Supply (RWS)}

The relative water supply is the ratio of supply water to demand. The relative water supply of the irrigation scheme is in Equation (4).

$$
\text { Relative water supply }(\text { RWS })=\frac{\text { volume of water allocated }}{\text { crop water requirement }}
$$

\subsection{Model Formulation}

A number of alternative objective function formulations are possible for the water allocation problem. The most appropriate function has been found to be of the form [27]:

$$
\text { Minimize } z=\sum_{i=1}^{n} \frac{\left(d_{i}-x_{i}\right)^{2}}{d_{i}}
$$

where $n$ is the number of irrigation schemes, $d_{i}$ the irrigation demand for scheme $i$ and $x_{i}$ the irrigation supply to scheme $i$. The Genetic Algorithm flow 
chart for the water allocation is shown in Figure 1. The above equation is subject to canal capacity constraints, and supply constraints defined mathematically as:

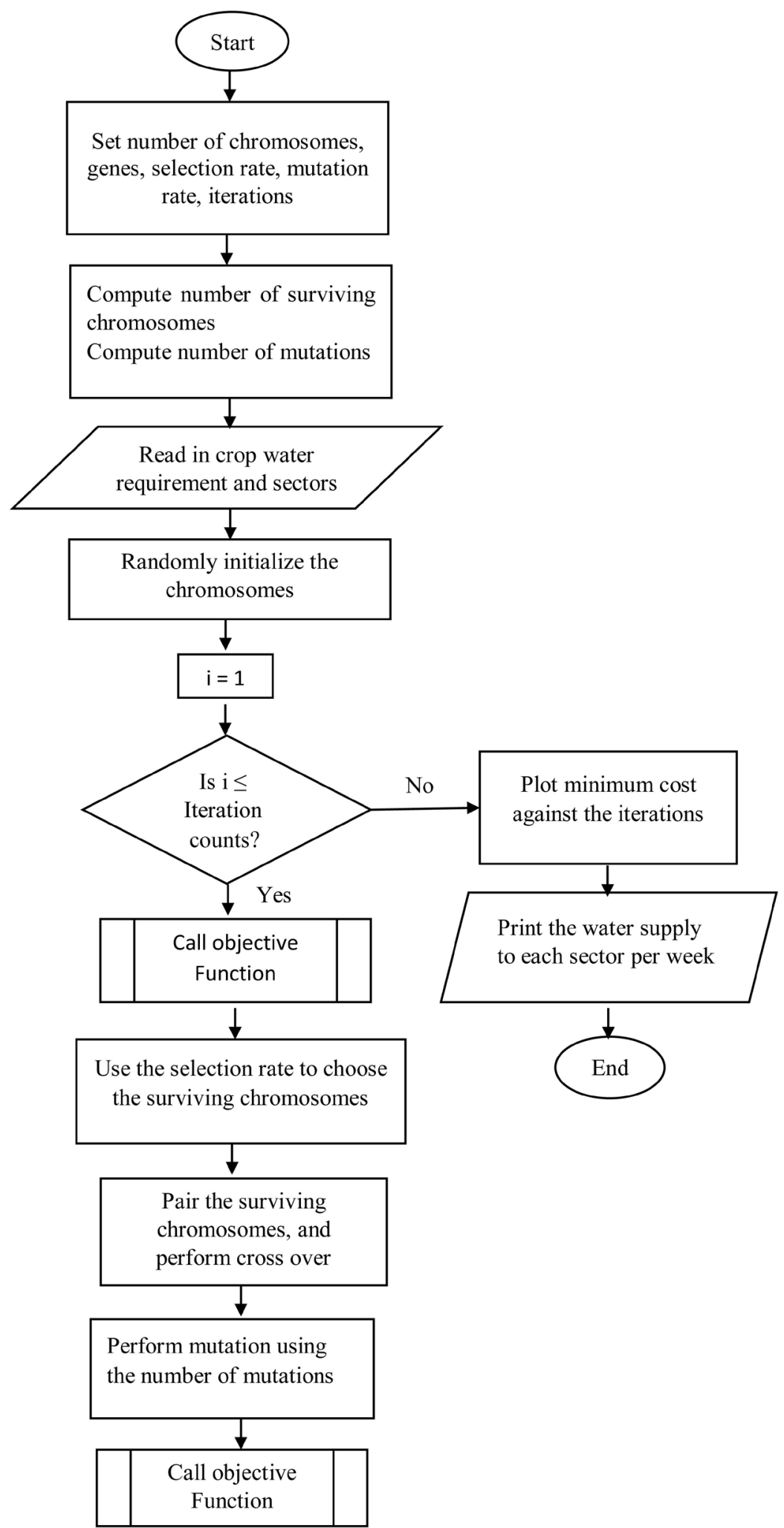

Figure 1. Flow chart for water allocation model. 


$$
\begin{aligned}
x_{i, w} & \leq d_{i} \\
\frac{x_{i, w}}{d_{i, w}} & \leq 1.0
\end{aligned}
$$

Equation (5) was rearranged to Equation (6)

$$
\text { Minimize } \mathrm{z}=\frac{\left(\sum_{i=1}^{52} \sum_{j}^{38} \operatorname{supply}_{i, j}-\min \left(\sum_{i=1}^{52} \sum_{j}^{38} \operatorname{demand}_{i, j}, Q\right)\right)^{2}}{\min \left(\sum_{w k=1}^{52} \sum_{j}^{38} \operatorname{demand}_{i, j}, Q\right)}
$$

where $i$ is the number of weeks, $j$ is the number of sectors and $Q$ is the weekly available water, subject to the constraint which states that the allocated supply to each sector should not exceed the minimum of either the weekly demand of each sector or the total weekly available supply was evaluated accordingly as in Equation (7).

$$
\operatorname{supply}_{w k, \text { sector }} \leq \min \left(\text { demand }_{w k, \text { sector }}, Q\right)
$$

The water allocation model was developed by employing Genetic algorithm (GA) optimization technique. The model was optimized by using Genetic Algorithm (GA) as in MATLAB 2013a. The objective function which minimizes the water allocated for the $t^{\text {th }}$ number of weeks to the $f^{\text {th }}$ number sectors is as shown in Equation (4). The flow chart for the objective function is shown in Figure 2.

\section{Results and Discussion}

The result of the reference evapotranspiration of Kano computed using the Penman-Monteith method is shown in Table 1 . The average monthly reference evapotranspiration ranges from $4.33 \mathrm{~mm} /$ day in August to $7.39 \mathrm{~mm}$ /day in April. This is partly accordance with the findings of [28], observed that evapotranspiration for Kano is very low in rainy season having lowest value in August and high during dry season with its highest value in February, although in the case of the study, the evapotranspiration was highest in April.

The crop water need ( $E T_{\text {crop }}$ ) was computed for each crop from Equation (2). The crops were planted at various weeks based on FAO 56 standard. The irrigation duration was for 36 weeks, when planting started in week 40 through week 23 of the next year.

Other details of the crops are presented in Table 2. It was observed that rice had the highest crop water need of $1124.71 \mathrm{~mm}$ although rice did not have the longest growth duration while maize had the lowest crop water need of 520.33 $\mathrm{mm}$ although maize did not have the longest growth duration. The crop water need is largely dependent on the crop factor of the crops at the different growth stages that the growth duration of the crops.

The crop water requirement for the entire irrigation scheme was then computed based on the crop water need based and cropping pattern of the Kano River Irrigation Project. The result of the crop water requirement is shown in Table 3. 


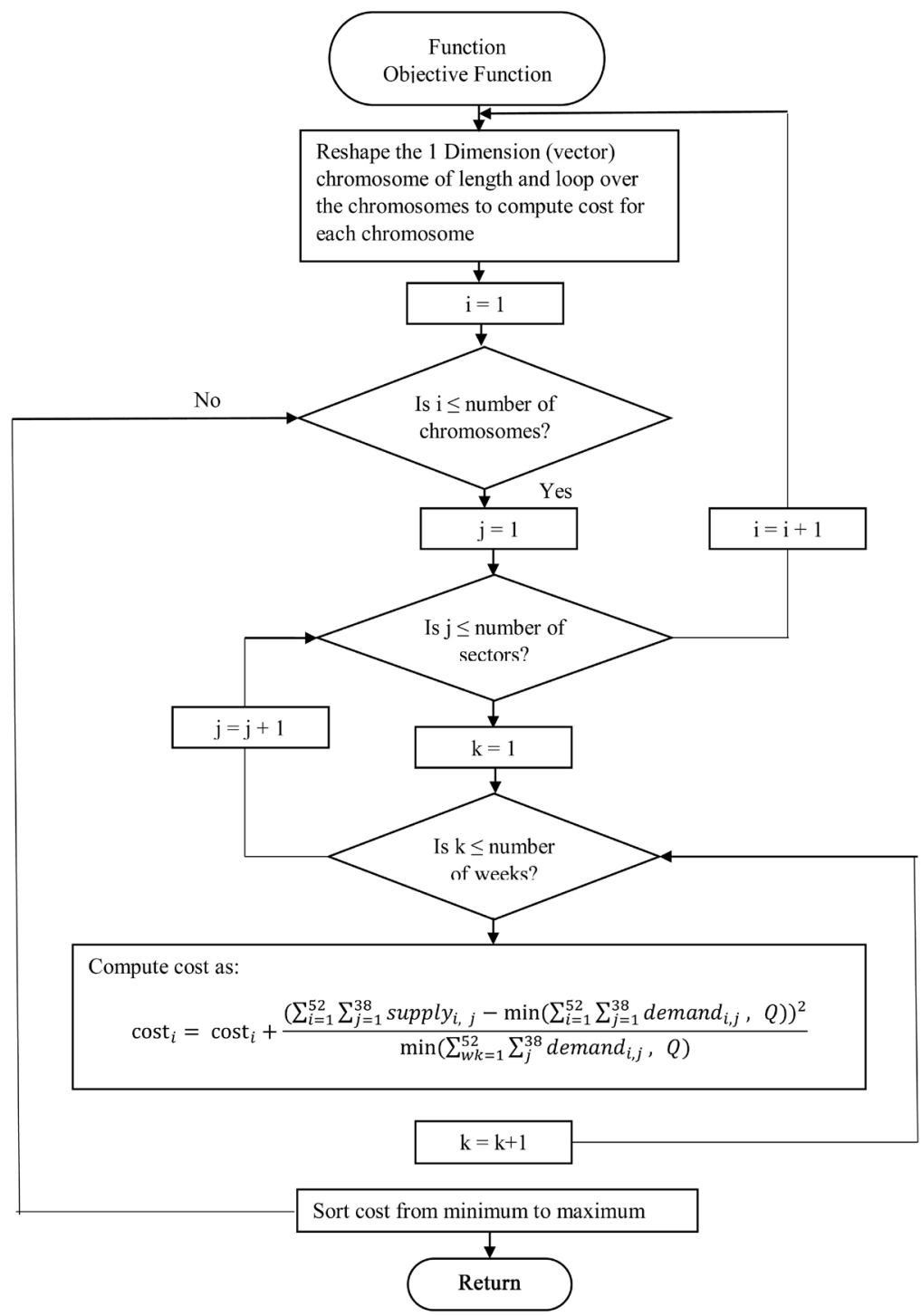

Figure 2. Flow chart of objective function for water allocation.

Table 1. Trend of Evapotranspiration (ETo) of KRIP.

\begin{tabular}{cc}
\hline Month & ETo $(\mathrm{mm} /$ day $)$ \\
\hline January & 5.52 \\
February & 6.33 \\
March & 6.98 \\
April & 7.39 \\
May & 6.95 \\
June & 5.86 \\
July & 4.84 \\
August & 4.33 \\
September & 4.85 \\
October & 5.51 \\
November & 5.69 \\
December & 5.49
\end{tabular}


Table 2. Irrigation characteristics for respective crops.

\begin{tabular}{cccccccc}
\hline Crop & Maize & Tomato & Wheat & Vegetable & Onion & Cowpea & Rice \\
\hline Planting week & 40 & 42 & 46 & 46 & 42 & 9 & 49 \\
$\begin{array}{c}\text { Harvest week } \\
\text { Total growth duration } \\
\text { (weeks) }\end{array}$ & 3 & 13 & 23 & 8 & 11 & 23 & 18 \\
$\begin{array}{c}\text { Total } E T_{\text {crop during }} \text { durowth (mm) } \\
\text { growth }\end{array}$ & 520.33 & 968.77 & 1018.34 & 546.55 & 778.61 & 557.12 & 1124.71 \\
$\begin{array}{c}\text { Minimum } E T_{\text {crop }} \\
\text { (mm/week) }\end{array}$ & 15.43 & 17.36 & 13.94 & 17.92 & 19.29 & 17.1 & 42.27 \\
$\begin{array}{c}\text { Maximum } E T_{\text {crop }} \\
\text { (mm/week) }\end{array}$ & 44.44 & 56.19 & 59.49 & 44.34 & 41.82 & 53.52 & 63.52 \\
\hline
\end{tabular}

Table 3. Crop water requirement of Kano River Irrigation Project in MCM.

\begin{tabular}{|c|c|c|c|c|c|}
\hline Month & Weeks & CWR (MCM) & Month & Weeks & CWR (MCM) \\
\hline \multirow{5}{*}{ October } & Week 40 & 0.172 & \multirow{4}{*}{ February } & Week 6 & 4.028 \\
\hline & Week 41 & 0.172 & & Week 7 & 4.082 \\
\hline & Week 42 & 0.555 & & Week 8 & 4.082 \\
\hline & Week 43 & 0.793 & & Week 9 & 4.439 \\
\hline & Week 44 & 0.793 & \multirow{4}{*}{ March } & Week 10 & 4.931 \\
\hline \multirow{4}{*}{ November } & Week 45 & 0.882 & & Week 11 & 4.964 \\
\hline & Week 46 & 1.053 & & Week 12 & 4.763 \\
\hline & Week 47 & 1.053 & & Week 13 & 4.771 \\
\hline & Week 48 & 1.668 & \multirow{5}{*}{ April } & Week 14 & 3.933 \\
\hline \multirow{4}{*}{ December } & Week 49 & 3.580 & & Week 15 & 3.873 \\
\hline & Week 50 & 3.722 & & Week 16 & 3.042 \\
\hline & Week 51 & 3.722 & & Week 17 & 2.981 \\
\hline & Week 52 & 3.727 & & Week 18 & 2.481 \\
\hline \multirow{5}{*}{ January } & Week 1 & 3.756 & \multirow{4}{*}{ May } & Week 19 & 0.496 \\
\hline & Week 2 & 3.783 & & Week 20 & 0.412 \\
\hline & Week 3 & 3.785 & & Week 21 & 0.277 \\
\hline & Week 4 & 3.237 & & Week 22 & 0.251 \\
\hline & Week 5 & 3.203 & June & Week 23 & 0.250 \\
\hline
\end{tabular}

The total crop water requirement for Kano River Irrigation Project was estimated to be 119.51 MCM with peak demand of 4.964 MCM obtained in week 11 . At full canal capacity, the weekly available water is $5.184 \mathrm{MCM}$. The weekly demand and the optimized release during the entire group period are shown in Figure 3. It was observed that the optimized release was very close to the demand for all the weeks during the entire growth period, supplying just what is needed by the crops. 
Table 4 shows the demand vs supply of all the 38 sectors in KRIP, it also shows the relative water supply of each sector. It was observed that the water allocated was closely matched with the demand (crop water requirement). Resulting to a $96.44 \%$ demand met. The GA Parameters used for the water allocation model are outlined in Table 5.

An overall optimized relative water supply of 0.96 was obtained for KRIP, with 0.94 and 0.99 as the minimum and maximum relative water supply respectively. The optimized relative water supply for Kadawa sector, Azore sector and Karfi sector where compared with those measured in the 90's in a study by [29]. Figures 4-6 show the minimum and maximum relative water supply for the three sectors respectively.

Table 4. Demand vs supply in MCM of the sectors and their relative water supply.

\begin{tabular}{|c|c|c|c|c|c|c|c|c|c|}
\hline & Sector & Demand & Supply & RWS & & Sector & Demand & Supply & RWS \\
\hline 1 & Waire & 1.74 & 1.67 & 0.96 & 20 & Pako & 1.26 & 1.20 & 0.95 \\
\hline 2 & Bangaza & 2.98 & 2.86 & 0.96 & 21 & Butalawa & 4.51 & 4.32 & 0.96 \\
\hline 3 & Yantomo & 1.89 & 1.82 & 0.96 & 22 & Majabo & 1.50 & 1.44 & 0.96 \\
\hline 4 & Kadawa & 1.11 & 1.05 & 0.95 & 23 & Karfi & 9.15 & 8.87 & 0.97 \\
\hline 5 & Gafan 1 & 0.12 & 0.11 & 0.95 & 24 & Yakassai & 3.60 & 3.45 & 0.96 \\
\hline 6 & Gafan 2 & 4.01 & 3.85 & 0.96 & 25 & Kosawa & 4.23 & 4.01 & 0.95 \\
\hline 7 & Agalawa & 1.52 & 1.46 & 0.96 & 26 & Gayere & 1.26 & 1.20 & 0.95 \\
\hline 8 & Raje & 1.21 & 1.14 & 0.94 & 27 & Dorawa & 3.83 & 3.67 & 0.96 \\
\hline 9 & Maura & 2.78 & 2.67 & 0.96 & 28 & Barnawa & 0.64 & 0.61 & 0.95 \\
\hline 10 & Kore & 17.57 & 17.35 & 0.99 & 29 & Shiye & 0.28 & 0.27 & 0.95 \\
\hline 11 & Azore & 0.68 & 0.65 & 0.95 & 30 & Chirin & 1.74 & 1.68 & 0.97 \\
\hline 12 & Samawa & 1.38 & 1.32 & 0.96 & 31 & Kode & 1.07 & 1.02 & 0.95 \\
\hline 13 & Gabas & 1.19 & 1.13 & 0.94 & 32 & Yuri & 0.65 & 0.63 & 0.97 \\
\hline 14 & Tsauni & 0.44 & 0.41 & 0.95 & 33 & Kuruma & 1.44 & 1.38 & 0.95 \\
\hline 15 & Rakauna & 2.12 & 2.03 & 0.96 & 34 & Turba & 1.28 & 1.22 & 0.95 \\
\hline 16 & Gori South & 0.89 & 0.85 & 0.96 & 35 & Tsambaki & 0.81 & 0.76 & 0.94 \\
\hline 17 & Gori North & 1.47 & 1.43 & 0.97 & 36 & Lautaye & 3.42 & 3.29 & 0.96 \\
\hline 18 & Agolas & 6.16 & 5.97 & 0.97 & 37 & Bunkure & 1.48 & 1.42 & 0.96 \\
\hline 19 & Balili & 0.56 & 0.54 & 0.96 & 38 & Korawa & 1.71 & 1.63 & 0.95 \\
\hline
\end{tabular}

Table 5. GA parameter for optimization of water allocation.

\begin{tabular}{cc}
\hline GA Parameter & Value \\
\hline Population size & 40 \\
Number of Genes & 1976 \\
Selection rate & 0.5 \\
Generations & 10,000 \\
Mutation rate & 0.2 \\
\hline
\end{tabular}


6.0

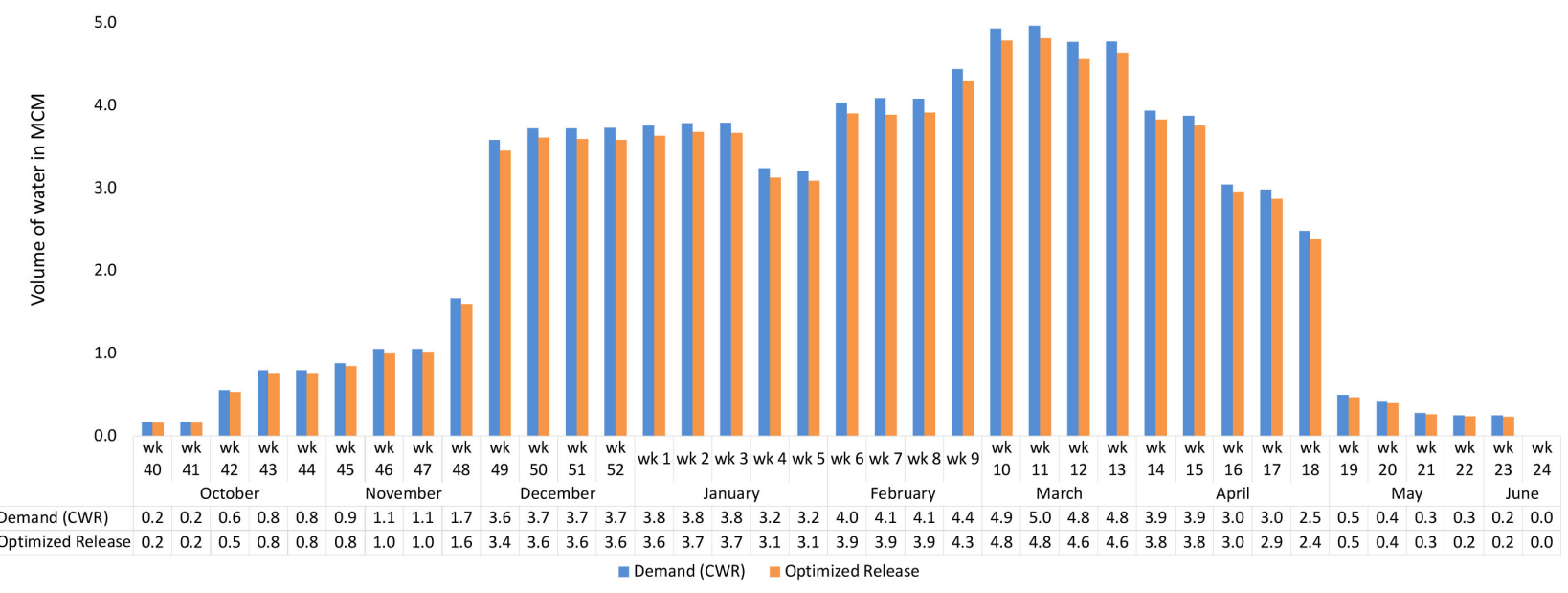

Figure 3. Demand vs optimized water release in Kano River Irrigation Project.

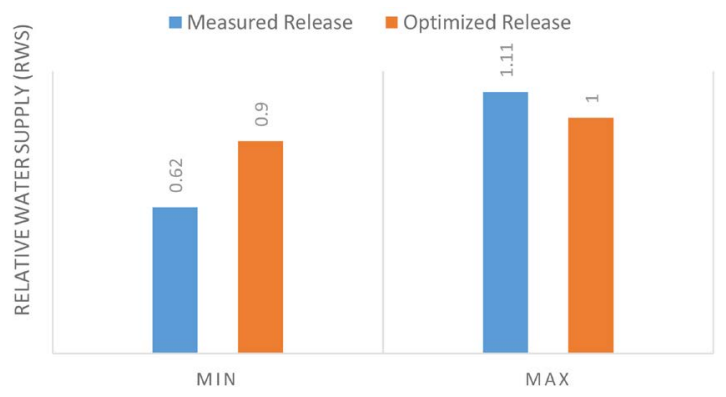

Figure 4. Optimized vs measured relative water supply of Kadawa sector.

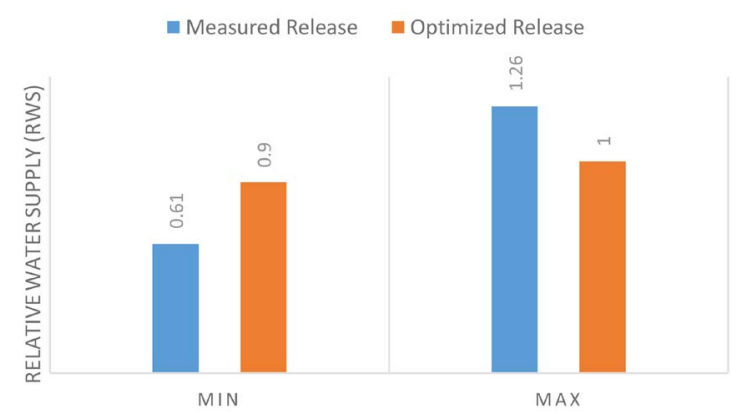

Figure 5. Optimized vs measured relative water supply of Azore sector.

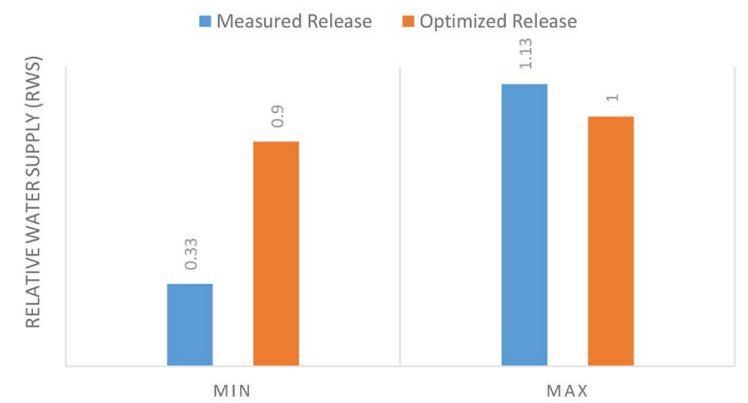

Figure 6. Optimized vs measured relative water supply of Karfi sector. 
It was observed that the measured relative water supplies indicates uneven supply of water during the planting season and also tail end problem, while the optimized relative water supplies indicates fairly uniform relative water supplies during the planning season also eliminating tail end problem.

\section{Conclusion}

The optimisation approach developed to minimize the gap between supply and crop water requirement based on the Genetic Algorithm optimization technique is robust and relatively easy to apply. Applying it to a real-time irrigation scheme, it has proven to be an effective tool in decision making tool for effective water allocation as the water allocation model yielded an optimal as well as equitable water release with a $96.44 \%$ demand met. An average relative supply of 0.94 was obtained indicating that there was even supply of water to all the sectors. The model can be employed by farm managers to achieve equity and optimal use of the available water resource.

\section{Conflicts of Interest}

The authors declare no conflicts of interest regarding the publication of this paper.

\section{References}

[1] WWF (2016) Living Planet: Report 2016: Risk and Resilience in a New Era. Worldwide Fund for Nature, Gland.

[2] WWF (2010) Living Planet Report 2010: Biodiversity, Biocapacity and Development. WWF (Worldwide Fund for Nature), Gland.

[3] De Fraiture, C., Molden, D. and Wichelns, D. (2010) Investing in Water for Food, Ecosystems, and Livelihoods: An Overview of the Comprehensive Assessment of Water Management in Agriculture. Agricultural Water Management, 97, 495-501. https://doi.org/10.1016/j.agwat.2009.08.015

[4] Steduto, P., Hoogeveen, J., Winpenny, J., Burke, J., et al. (2017) Coping with Water Scarcity: An Action Framework for Agriculture and Food Security. Food and Agriculture Organization of the United Nations, Rome.

[5] Pastor, A., Palazzo, A., Havlik, P., Biemans, H., Wada, Y., Obersteiner, M., Kabat, P. and Ludwig, F. (2019) The Global Nexus of Food-Trade-Water Sustaining Environmental Flows by 2050. Nature Sustainability, 2, 499-507. https://doi.org/10.1038/s41893-019-0287-1

[6] Levidow, L., Zaccaria, D., Maia, R., Vivas, E., Todorovic, M. and Scardigno, A. (2014) Improving Water-Efficient Irrigation: Prospects and Difficulties of Innovative Practices. Agricultural Water Management, 146, 84-94. https://doi.org/10.1016/j.agwat.2014.07.012

[7] Hellin, J. and Fisher, E. (2019) Climate-Smart Agriculture and Non-Agricultural Livelihood Transformation. Climate, 7, 48. https://doi.org/10.3390/cli7040048

[8] Kummu, M., Gerten, D., Heinke, J., Konzmann, M. and Varis, O. (2014) Climate-Driven Interannual Variability of Water Scarcity in Food Production Potential: A Global Analysis. Hydrology \& Earth System Sciences, 18, 447-461. https://doi.org/10.5194/hess-18-447-2014 
[9] Imran, M.A., Ali, A., Ashfaq, M., Hassan, S., Culas, R. and Ma, C. (2019) Impact of Climate Smart Agriculture (CSA) through Sustainable Irrigation Management on Resource Use Efficiency: A Sustainable Production Alternative for Cotton. Land Use Policy, 88, Article ID: 104113. https://doi.org/10.1016/j.landusepol.2019.104113

[10] Makate, C., Makate, M., Mango, N. and Siziba, S. (2019) Increasing Resilience of Smallholder Farmers to Climate Change through Multiple Adoption of Proven Climate-Smart Agriculture Innovations. Lessons from Southern Africa. Journal of Environmental Management, 231, 858-868.

https://doi.org/10.1016/j.jenvman.2018.10.069

[11] Faurès, J., Bartley, D., Bazza, M., Burke, J., Hoogeveen, J., Soto, D. and Steduto, P. (2013) Climate Smart Agriculture Sourcebook. FAO, Rome, 557.

[12] Rao, N. (2018) Big Data and Climate Smart Agriculture-Status and Implications for Agricultural Research and Innovation in India. Proceedings of the Indian National Science Academy, 84, 625-640. https://doi.org/10.16943/ptinsa/2018/49342

[13] Nwa, E.U., et al. (2003) History of Irrigation, Drainage and Flood Control in Nigeria from Pre-Colonial Times to 1999. Spectrum Books.

[14] Bayero, M.T. (2019) Assessing the Sustainability of Drainage System in Irrigated Agricultural Land: A Case Study of Kano River Irrigation Scheme in Nigeria.

[15] Burney, J.A., Naylor, R.L. and Postel, S.L. (2013) The Case for Distributed Irrigation as a Development Priority in Sub-Saharan Africa. Proceedings of the National Academy of Sciences, 110, 12513-12517. https://doi.org/10.1073/pnas.1203597110

[16] Mallam, M., Agbo, F., Ebe, F., et al. (2014) Resource Use Efficiency among Beneficiaries and Non-Beneficiaries of Fadama Rice Project in Niger State, Nigeria. International Journal of Agricultural Research, 9, 294-303.

https://doi.org/10.3923/ijar.2014.294.303

[17] Omorogiuwa, O., Zivkovic, J. and Ademoh, F. (2014) The Role of Agriculture in the Economic Development of Nigeria. European Scientific Journal, 10, 133-147.

[18] Lowder, S.K., Bertini, R., Karfakis, P. and Croppenstedt, A. (2016) Transformation in the Size and Distribution of Farmland Operated by Household and Other Farms in Select Countries of Sub-Saharan Africa.

[19] Ukamaka, D.M., Danjuma, S.E., Mbolle, C.J., Innocent, E. and Mbadiwe, I. (2017) Livelihood Issues in Herdsmen-Farmers' Conflict among Farming Communities in Kogi State, Nigeria. African Journal of Agricultural Research, 12, 2105-2115. https://doi.org/10.5897/AJAR2017.12319

[20] Adekunle, O., Oladipo, F. and Busari, I. (2015) Factors Affecting Farmers' Participation in Irrigation Schemes of the Lower Niger River Basin and Rural Development Authority, Kwara State, Nigeria. South African Journal of Agricultural Extension, 43, 42-51. https://doi.org/10.17159/2413-3221/2015/v43n2a353

[21] Adelodun, B. and Choi, K.-S. (2018) A Review of the Evaluation of Irrigation Practice in Nigeria: Past, Present and Future Prospects.

[22] Mohammed, M., Abdulhamid, A., Badamasi, M. and Ahmed, M. (2015) Rainfall Dynamics and Climate Change in Kano, Nigeria. Journal of Scientific Research and Reports, 7, 386-395. https://doi.org/10.9734/JSRR/2015/17098

[23] Akpootu, D. and Iliyasu, M. (2015) A Comparative Study of Some Meteorological Parameters for Predicting Global Solar Radiation in Kano, Nigeria Based on Three Variable Correlations. Advances in Physics Theories and Applications, 49, 1-9.

[24] Patel, J. and Balve, P. (2016) Evapotranspiration Estimation with Fuzzy Logic. Proceedings of 40 th the IRES Conference, Zurich, 20-23. 
[25] Jangre, N., Sinha, J., Sujatha, G. and Patel, A. (2017) Modelling of Daily Reference Evapotranspiration Using Fuzzy Logic for Chhattisgarh Plains. International Journal of Data Mining and Emerging Technologies, 7, 16-22.

https://doi.org/10.5958/2249-3220.2017.00003.9

[26] Allen, R.G., Pereira, L.S., Raes, D., Smith, M., et al. (1998) Crop Evapotranspiration-Guidelines for Computing Crop Water Requirements. FAO Irrigation and Drainage Paper 56. FAO, Rome, 300, D05109.

[27] Wardlaw, R., Moore, D. and Barnes, J. (1997) An Assessment of the Potential of Optimisation in Real Time Irrigation Management. In: Water. Economics, Management and Demand, CRC Press, Boca Raton, 211.

[28] Isikwue, C.B., Audu, O.M. and Isikwue, O.M. (2014) Evaluation of Evapotranspiration Using FAO Penman-Monteith Method in Kano Nigeria. International Journal of Science and Technology, 3, 698-703.

[29] Jimoh, O.D. (1992) On Equity of Water Distribution System to Kano River Project. Proceedings of the 16th Annual Conference of Nigerian Society of Agricultural Engineers, Minna, 8-13. 